\title{
Debating China
}

\section{"After China, It Had Been Impossible": China, History and Sexual Anxiety in Brian Castro's After China}

\section{Marilyne BRUN}

\section{(2) OpenEdition \\ Journals}

Édition électronique

URL : http://journals.openedition.org/transtexts/403

DOI : $10.4000 /$ transtexts.403

ISSN : 2105-2549

Éditeur

Gregory B. Lee

Édition imprimée

Date de publication : 7 avril 2011

ISSN : 1771-2084

Référence électronique

Marilyne BRUN, "After China, It Had Been Impossible": China, History and Sexual Anxiety in Brian Castro's After China », Transtext(e)s Transcultures 跨文本跨文化 [En ligne], 6 | 2011, mis en ligne le 05 avril 2011, consulté le 20 avril 2019. URL : http://journals.openedition.org/transtexts/403 ; DOI : $10.4000 /$ transtexts. 403 


\title{
Transtext(e)s Transcultures 跨文本跨 文化
}

Journal of Global Cultural Studies

6 | 2011:

Debating China

\section{"After China, It Had Been Impossible": China, History and Sexual Anxiety in Brian Castro's After China}

\author{
MARILYNE BRUN
}

\section{Résumés}

This paper focuses on the fourth novel of contemporary Australian writer Brian Castro, After China (1992), and discusses the central importance of sexual anxiety to the work. The main character of the novel, a Chinese architect who migrated to Australia after the Cultural Revolution, is left both castrated - he had a serious train accident that annihilated all possibilities of having children - and unable to have sex after his traumatic ordeals in China. Significantly, the character represents China in dichotomous terms, since he draws a strict opposition between a sensual, free ancient China and a threatening, oppressive contemporary China. His sexual anxieties thus inform his binary representation of China, articulate the structure of the novel, but also involve a critique of biopolitics and its impact on individual sensibilities and intimacies.

Cet article aborde le quatrième roman de l'auteur australien contemporain Brian Castro, After China (1992), et étudie le rôle central de l'anxiété sexuelle dans l'œuvre. Le personnage principal du roman, un architecte chinois qui a émigré en Australie après la Révolution Culturelle, se trouve face à une double impossibilité après son expérience en Chine : victime d'un grave accident de train, il perd la capacité d'avoir des enfants ; choqué par son expérience de la répression, il se retrouve incapable de faire l'amour. Le personnage représente la Chine en termes binaires, puisqu'il établit une opposition stricte entre une Chine ancienne libre et sensuelle et une Chine contemporaine menaçante et opprimante. Ses angoisses sexuelles conditionnent donc sa représentation binaire de la Chine, articulent la structure du roman, mais impliquent aussi une critique 
de la biopolitique et de son impact sur les sensibilités et les intimités de chacun.

\section{Texte intégral}

The title of Brian Castro's fourth novel, After China (1992), suggests that "China" - whatever reality and experience the term may refer to - represents a major turning point in the work. ${ }^{1}$ The title both situates the action of the novel after China, thereby distancing the main character from his experience in the country, while at the same time paradoxically positioning "China" at the very centre of his life. China is at once rejected ("after") and determining ("after China"), an ambivalent status that articulates the very structure of the novel. After China focuses on You Bok Mun, a Chinese architect who migrated to Australia after the Cultural Revolution. As the title of the novel suggests, his experience in China is both wrapped in silence and central to his life in Australia. ${ }^{2}$ The novel's present is defined in relation to China, not Australia, and You's life in Australia is only implied through the reference to a Chinese past. Yet the title of the novel takes all its significance when You explains that his experience in China left him both castrated - he had a serious train accident that annihilated all possibilities of ever having children again - and unable to have sex: "After China, it had been impossible". ${ }^{3}$ For You's representation of China largely stages his own sexual anxieties: China is apprehended in terms of eroticism in the novel, its complex history and politics crystallised in contrasting representations of sexuality.

2 After China is perhaps less a novel about China than a love story and a narrative about loss and mourning. It centres on the relationship of Chinese architect You Bok Mun with an unnamed woman writer who is dying of cancer (presumably). ${ }^{4}$ The narration is not linear, but moves from the present - when the writer is dead - to various moments in their relationship, adulthood and childhood. The two characters' encounters involve accounts and reminiscences of their conversations, but they also comprise fictional stories that the protagonists narrated to each other, which include stories about their past, as well as several stories narrated by You and taking place in ancient China. ${ }^{5}$ The setting for much of the two main characters' relationship is the hotel built by You, an experimental, transient structure perched on a cliff and partly underwater. Beyond the tragedy of the lovers, the narrative conveys a sense of intimacy, a connection between the architect and the writer that rises against the odds - her illness, his foreignness, their difficult pasts.

3 Although the two characters meet sporadically, they develop a unique intimacy that allows them to share painful stories from their pasts. The lurking presence of death is palpable throughout the novel, and sets temporal and physical limits to their relationship. The multiplicity of layers that can be found in the novel presents the reader with a kaleidoscopic work, whose colours change continuously. Both tragic and funny, it is indeed one of Castro's "richest and most concise" novels. ${ }^{6}$ As Katharine England has remarked, After China is "at once a tender love story, a meditation on sex and death, and an exploration of the uses of narrative". 7 Yet the 153-page novel is also a reflection on architecture, migrancy, political oppression and sexual anxiety.

4 The life of the main character of the novel, You, is presented in fragments, with both direct narrations and indirect representations of his past. Indeed, the fictional stories that he tells the writer about ancient China do not simply 
function as entertainment pieces, since they indirectly provide a platform for You to express his own anxieties. As the novel progresses, readers learn that You was severely injured by a train when he was re-educated in a camp during the Cultural Revolution. Matter-of-factly, he states: "Then the doctor said I would never have children. He gave ether to put on the wound" (p.98). Literally castrated by his experience in China, You further finds himself unable to make love "after China" (p.37). "China" therefore operates as a symbol for his sexual anxieties, which intricately articulate converging reflections about time, death, political oppression and sexuality in After China.

\section{Ancient China's Sexual Economy}

Just as the title of the novel gives a sense of binarism to the life of You - his life before China is set in direct contrast with his life after China - his representation of China similarly oscillates between two extremes: a playful, free ancient China and a threatening contemporary China. This dichotomous approach does not simply mirror his trauma, it also offers a critique of the relation between politics and sexuality. The stories that You and the writer share perform a number of functions in the novel, since they act, as England has remarked, "as introduction, conversation, seduction, contraception, protection". ${ }^{8}$ The threatening progression of time - the ever-nearing death of the writer - is somehow suspended during storytelling:

"When I listen to your stories, time no longer seems to matter."

"Then we will tell each other more, whenever we can, and nothing will be terminated," he says. (p.88)

As in The Arabian Nights, storytelling postpones the arrival of death and provides a means of controlling time. As David Brooks suggests, After China reverses the dynamic of The Arabian Nights, since the main story-teller - You - is not threatened by death. ${ }^{9}$ The novelcontains two narrators, and each story is part of an extended dialogue between You and the writer, several stories being told as a response to the story of the other character: You "worked his jaw. Her story needed a counter" (p.84). But while storytelling rehabilitates the King and saves Scheherazade in the Arabian Nights, in After China it rather represents a reflection on the subjective and elastic nature of time.

Such desire to control time is also evoked in You's stories on ancient China, which feature several important figures in Taoism. Laozi, who is generally regarded as the founder of Taoism, is the main character of the first chapter and features throughout the novel. ${ }^{10}$ Zhuangzi [spelt Chuang-tzu in the novel], who is culturally regarded as Laozi's intellectual and spiritual successor, is the main character of You's final story. Taoism is also present through You's stories on alchemist Lü Ta-ching. It is significant that Castro should have chosen to focus so extensively on Taoism in the novel, for Taoist alchemy represents a unique articulation of concerns over time, mortality and sex.

8 In the second volume of his History of Sexuality, Michel Foucault argues that two main types of anxieties characterised the approaches adopted by ancient cultures: the fear that sex was detrimental to health, and concerns surrounding the desire to control procreation. ${ }^{11}$ The fear that sex could cause a loss of strength or premature death was addressed in different terms depending 
on the context. While ancient Greek thought endorsed a "tendency towards a restrictive economy", Taoism suggested that a certain practice of sexual intercourse - the retention of semen - could reinforce men's health and exorcise time. ${ }^{12}$ Robert Hans van Gulik similarly explains that Taoist philosophy generally regarded semen as the source of a man's health and life, and therefore commended that it should not be wasted. ${ }^{13}$

Taoism suggested that men could strengthen their essence (yang) by having sexual intercourse with women without emission. According to this sexual alchemy, the intercourse was of benefit for both man and woman: while the man absorbs the woman's yin essence, the woman benefits from having her yin stimulated. ${ }^{14}$ Some Taoist schools developed the belief that sexual alchemy could lead to immortality, and could hence challenge time and mortality. ${ }^{15}$ It is therefore not surprising to find a large number of Taoist references in After China, a novel in which both time and sexuality are the site of great anxieties. You's inability to have sex with the writer is partly compensated by his erotic narratives on ancient China, and the chastity of their relationship is somewhat justified by the Taoist desire to control and limit sexuality.

You's descriptions of ancient China thus evoke a specific sense of sexual economy: the era is paradoxically characterised by a sense of both restriction and excess. Sex is a common occurrence and a main topic of conversation, yet its enactment is characterised by a restrictive economy dominated by the need to retain semen. Concerns over sexuality in ancient China are formulated in terms of the effects that sexuality may have on individual bodies. Ancient China is defined by a sexual economy that is a unique response to individual anxieties over time, health and mortality, an attitude that widely differs from contemporary China's as described by You.

Perhaps surprisingly, You's stories on ancient China are characterised by a humorous tone that parodies Taoist attempts at controlling time. Taoist figures and their endeavours to master Taoist alchemy are largely derided in the novel. After China starts with a parodic chapter on Chinese philosopher and deity Laozi in 499 B.C. Laozi is at first respectfully presented as a "venerable philosopher", "an Immortal" (p.1). Respect for the philosopher is however shattered at the end of the second paragraph, where the narrator states that Laozi's pronouncements on health had been "stale and technical" (p.1). The first two paragraphs of the chapter reflect its structure, for it inevitably oscillates between reverence and mockery. While Laozi's philosophical reflections are conveyed through long, balanced sentences, his activities are gradually presented as amusing and grotesque. Sex is inappropriately excessive: the Tiger potion that Laozi is taking made one of his acquaintances so "insatiable" that his wife "took out an injunction, complaining that his attentions had devastated her" (p.1). Laozi, who has managed to have sex 1,199 times in the year without emission, grotesquely gives in to brevity (p.3). ${ }^{16} \mathrm{Sex}$ almost works as an excuse for sensuality in the name of spiritual pursuit. ${ }^{17}$ Laozi's death is finally parodied through the intervention of modern scientific discourse, which breaks away from the chapter's valorisation of philosophical mysticism:

For a brief moment he felt buoyant, almost mythical, and then was dead forever, from what modern physicians now surmise as cancer of the prostate. $(\text { p. } 3)^{18}$ 
Zhuangzi, Laozi's intellectual successor, does not fare much better in the novel. The first seven chapters of Zhuangzi's eponymous volume of philosophy include the well-known butterfly dream:

Once Chuang Chou dreamt he was a butterfly. He was happy as a butterfly, enjoying himself and going where he wanted. He didn't know he was Chou. Suddenly he awoke, whereupon he was startled to find he was Chou. He didn't know whether Chou had dreamt he was a butterfly, or if a butterfly were dreaming it was Chou. But as Chou and the butterfly, there must be a distinction. This is called the transformation of beings. ${ }^{19}$

While Zhuangzi's dream deftly highlights the unity of all beings and the ambiguity of reality, the butterfly dream is evoked in very different terms by one of You's ancient Chinese characters, Tang Yin, in After China:

\begin{abstract}
He writes about a wet dream he had, in which he dreamt he was a butterfly. He realises that someone else has had this dream before. In the words of the Chou philosopher Chuang-tzu: Am I dreaming I am a butterfly, or is the butterfly dreaming that it is me? Tang Yin is overcome by an uncanny feeling of guilt. Is it illicit to dream someone else's dream? (pp.104-105)
\end{abstract}

Through the character of Tang, You interestingly chooses to shift the meaning of Zhuangzi's dream to discuss sexuality and voyeurism: the philosophical content of the dream is completely discarded in favour of self-centred eroticism.

15 You's final story to the writer extends the erotic content of the butterfly dream. In the story, You narrates the tale of Zhuangzi, "a butterfly who thought he was a philosopher" (p.146). The butterfly "believed he had designed everything, believed that it was his wisdom which enabled this cultivation to continue" (p.146). Imbued with a sense of self-importance, the butterfly tries to re-educate Amazonian lilies about the artificiality of their environment. He finally dies erotically in the "moist and warm" centre of a vermilion lily, "his heart stopping in this feverish intercourse" (p.147). You's story offers a stinging parody of Zhuangzi's philosophy. It goes against the very foundation of Zhuangzi's reflection, since it discards the main point of the parable by asserting that Zhuangzi is a butterfly. Zhuangzi's arrogance and narrowmindedness challenges his credibility as a philosopher. Indeed the conceit and erotic death of Zhuangzi directly evokes the parody of Laozi, where philosophical enquiry is undertaken by an arrogant and flawed man. ${ }^{20}$

Castro's playful representation of Laozi and Zhuangzi does not seem primarily aimed at challenging the authority of the philosophers, since his parody is essentially structured around inappropriate attitudes towards sexuality. Rather, the stories represent a means for You to stage and project his own sexual anxieties onto the philosophers. His story on Zhuangzi, which represents a pause, a slowing down of the pace at a moment of rush and tragedy, is particularly significant in this respect. While You's hotel threatens to sink into the sea and the woman writer is about to die, You stops in one of the hotel's alcoves to accompany the writer towards her death through a last narrative. The final story - that of Zhuangzi - is the culmination of a series of images that appear throughout the novel and a synthetic amalgamation of You's stories. ${ }^{21}$ In You's narration, Zhuangzi the butterfly arrogantly tries to educate lilies about their environment and dies unsuccessful, erotically situated 
at the centre of a vermilion lily. The butterfly, dying in the lily,

was finally borne away by her memory of a spring flood, down-river to a dawn of angelic choirs... and while he died, she lived on in her multiplicity and her voices called to him, though he was beyond listening. (p.147, my emphasis)

You's choice to gender the butterfly and the vermilion lily establishes parallels between the male butterfly and You on the one hand, and the female lily and the writer on the other hand. You therefore narrates his metaphorical death from sorrow in the Zhuangzi story, while the writer dies but is given immortality, since she "live[s] on in her multiplicity", calling to her lover, who cannot hear, paralysed with pain. ${ }^{22}$

Zhuangzi's story also narrates - and thereby enacts - a sexual union between You (the butterfly) and the writer (the vermillion lily), so that the narrative is also a representation of, and a symbolic challenge to, You's sexual anxieties. Unable to have sex or children since his experience in China, You had a chaste relationship with the writer. The novel mentions one kiss. The night before the writer's death: "You had hardly touched her until now. In that long night he traced his finger along her body, memorised her form in that draftsman-like habit of his" (p.138). The eroticism that characterises You's tales on ancient China is thus not simply a reflection of Taoist experimentations with sexuality and immortality. It also emphasises the respectful chastity of his relationship with the writer and represents a narrative compensation for the sexuality that he is unable to offer her. In this light, his final story on Zhuangzi metaphorically enacts their sexual union, thus staging a symbolic reconciliation with sexuality for You. ${ }^{23}$ The stories on Laozi and Zhuangzi can therefore be addressed as experimental stages that allow You to explore eroticism and sensuality and thereby overcome his trauma and anxieties.

However, You's parodic stories on ancient China are also essential to the novel because they are set in direct contrast to You's representation of contemporary China. Indeed the significance of Castro's parody of Laozi and Zhuangzi does not so much lie in what is being parodied than in the sheer possibility of parodying. You's fictional narratives on ancient China are erotic and infused with a sense of celebration and personal freedom. In his stories, ancient China is a light-hearted era that put great emphasis on enjoying life and sensuality. The playfulness of You's ancient China contrasts very heavily with the gravity of contemporary China. And this opposition is made visible in the novel through their contrasting attitudes towards sexuality and its inclusion in political structures.

\section{Chinese Modernity and the Rise of Biopolitics}

Contemporary China is described and approached in very different terms than ancient China in After China. While ancient China is the site of playfulness, sensuality and enjoyment - despite the inevitable presence of political intrigues and plots - contemporary China is characterised by a sense of authoritarianism and of imposed taboos on sexuality, parody and criticism. 
The shift from the intellectual, political and sexual freedom that - in You's imaginary - characterised ancient China to the confining atmosphere of contemporary China is evoked in two key passages in the novel, where the transition to modernity is described as a traumatic moment of danger and loss.

When You's father - Fishcake - is initiated to the forbidden and erotic secrets of foot binding by his aunt in 1909, he is faced with an intriguing piece of advice:

The transition from ancient to modern can come at any time, she said. In China it can come at any time at all. Time itself is not of great importance, but the transition is dangerous. We have no experience of it. [...] It is only survivable if you avoid emission [...] Lightness, delicacy and restraint, she repeated. Moderation... that is how you will survive change. (pp.43-44)

Fishcake's beautiful aunt suggests that change can only be survived through the principle of moderation, a clear reference to Taoism. For her, only tradition and a sense of history can ensure the continuity needed in times of change. Her words imply that the progressive discard of Taoism, Confucianism and of Chinese cultural and historical traditions by communist authorities necessarily signified the impossibility of surviving these political changes. ${ }^{24}$

This nostalgic longing for a lost history is also clear in You's experience. When he visits the writer at her house, he finds himself unable to reduce the gap between them and dance with her. This inability is linked to a loss of history and therefore of erotic traditions, which strangely inhabit him but cannot be brought to the surface: "All these gestures inhabiting me, and yet I know nothing of them, gestures of a dead father whom I hardly knew" (p.101). His inability to dance is linked to the communist government's discard of the past. He feels

driven by the importance of being hard, sceptical and ironic, in search of that lost world which never existed [...], between the cruel, exploited China and the crude totalitarian one; [...] all adrift from having abandoned history from the very beginning. (p.102, my emphasis)

China's failure, the novel suggests, lies in its discard of the past and censoring of the present, in its authoritarian imposition of a single narrative. ${ }^{25}$ In this sense, the architect's constant evocation of ancient China in his stories actively resists the monologism offered by China. His evocation of his father's glory in pre-communist China also condemns China's contemporary regime and celebrates the idyllic glory of colonial Shanghai. ${ }^{26}$

Eroticism is presented as a redeeming force for China. Dining with the writer, You's foot touches hers:

what I felt like I couldn't describe... yes, I felt as if this could have been the transformation of China... the teaching of sexual practices to the world... an opening out. I felt that history could have been made... the course of her civilisation altered. (p.55)

Between the novel's two Chinas, there is a clear historical trauma. Between the joyous, luxurious, erotic ancient China and the bleak, repressive, authoritarian contemporary China lies the failed transition to modernity and its consequences.

The warnings uttered by Fishcake's aunt and the nostalgia for a lost golden 
age are largely reinforced by You's negative representation of contemporary China, which is characterised by an oppressive sense of danger and threat. Far from the playful sensuality of ancient China, Shanghai is primarily described as dangerous and oppressive:

If he has to describe life in Shanghai he would use just one word: commotion. People run over by bicycles. Security police chasing somebody. The old women in the work unit speaking of war and detention. Pickpockets beaten on street corners. [...] Oh yes, and gossip could try, sentence and execute you. But you always knew when things loosened up, because out came the snake charmers and martial arts experts.

For now, everyone keeps his eyes on the ground.

You also know you're being watched. Around the corner an old man keeps a notebook on proceedings. (p.12) ${ }^{27}$

Central to this short description is the pervasive presence of control and repression. You feels constantly observed by official forces (the police) but also by fellow citizens (the old man). Yet the sense of danger mostly pertains to the randomness of the threat: gossip works as a powerful, invisible threat. In the re-education camp, You similarly experiences the lack of identifiable landmarks and rules when he is faced with the impossibility of guessing the confession that officials expect:

I have re-written this confession eighty-three times. [...] I edited each time, but that is not what they want. [...] I know only of one [crime]: the plaque outside the pagoda I built in the People's Park. But they do not want to know about that because it never existed. (p.90)

When You lists the four layers of fear that he has experienced, he clearly grades the different types according to the pervasiveness and potential identification of the threat:

- Fear generated by an identifiable source.

- Fear generated by something unknown.

- Fear that is sporadic, striking at the oddest moments, ending in complete powerlessness and humiliation.

- Constant fear beyond any objective situation or event. The point at which madness intervenes; a kind of automatic shutdown. (p.25)

The pervasiveness of terror is nowhere clearer than in his ironic reference to the Great Leap Forward: "Nights he felt as free as the sparrows searching out a new place to sleep" (p.131). You's stinging reference to the Great Leap Forward directly associates the terror imposed on him with the constant harassment of sparrows, emphasising the catastrophic consequences of both the Great Leap Forward and a regime of fear. ${ }^{29}$

Significantly, China's regime of fear also concerns the private world of sexuality. Political oppression and the repression of eroticism are deeply associated in the novel. Sexual repression is enacted through laws:

Students are not to fall in love, drink wine or smoke cigarettes. - Article 441. (p.32)

He read in the newspaper the other day: From October 1991, hugs, kisses, putting one's arm around another's shoulder and hand-holding will be forbidden in Chinese universities. - Article 542. (pp.65-66)

Love itself is made "a forbidden topic" (p.65), and You was re-educated to see 
"the crime of love [...] as decadent imagination" (p.99).

It is useful to return to Foucault's work on sexuality at this stage. In The Use of Pleasure, Foucaultestablishes a crucial connection between sexuality and politics. The work of ancient Greek rhetorician Isocrates, he argues, explicitly connected sexual practices and the exercise of political power. Isocrates saw a direct continuity between the government of a state and the government of a household, arguing that the nature of rulers' private life could be seen as a reflection of their ability to govern. ${ }^{30}$ While the prince's sexual virtue is seen as a necessary condition for the exercise of power, the sexual virtue of citizens is by extension often apprehended as a way of ruling them.

In an essay entitled "The Private and the Public: A Meditation on Noise", Castro explores the implications of Foucault's argument in relation to his own practice as a writer. ${ }^{31}$ He takes the example of the Chinese government's refusal to circulate contraceptives to unmarried couples. Contraception, he argues, is a symbol of Western bourgeois decadence and was therefore rejected by the communist government. ${ }^{32}$ However, Castro proposes that the crux of the question does not lie in the confrontation of communist and capitalist ideologies, but that the government's refusal is rather based on the centrality of sexual control to the exercise of political control. Castro concludes that the desire of the Chinese government to control sexual relations through laws is really a means of controlling the Chinese population at a political level.

It is essentially this centrality of biopolitics to contemporary Chinese political practice that Castro criticises in his contrasting representations of the sexualities of ancient and contemporary China in After China. Foucault has largely commented on the importance of controlling and codifying the discourses surrounding sexuality in the control of bodies and therefore in the production of power. ${ }^{33}$ His concepts of biopolitics and biopower describe the emergence, from the eighteenth century onwards, of a form of power that starts managing life itself, and therefore seeks to control bodies and regulate populations. ${ }^{34}$ For Foucault, biopower marks a new stage in the evolution of power structures, since power stops being concerned with the old principle to let live or kill and progressively aims at enhancing both productivity and its own efficiency through an increasing control over its populations. ${ }^{35}$ Foucault thus identifies the emergence after the eighteenth century of the notion of a social body that is the object of government, the discovery of "the body as an object and target of power" (le « corps comme objet et cible du pouvoir »). ${ }^{36}$

The dichotomy that is established between the sexual practices and anxieties of ancient and contemporary China in After China is therefore not solely a reflection of the main character's sexual anxieties. It is also a denunciation of the mobilisation of sexuality as a form of power and influence by Chinese authorities. Ancient China is characterised by You as an era when sexual anxieties were apprehended in terms of the passing of time, health and mortality - that is, in terms of the effects of sex on individuals. In contrast, in his narratives on sexual anxieties in contemporary China do not pertain to anxieties about individual bodies, but about the need for authorities to control bodies - the sites and objects of power. After China thus traces a shift in sexual anxieties from individual concerns about health and mortality to political concerns about the control of populations and the subjugation of bodies.

The strict opposition that You draws between ancient and contemporary China is thus a staging of his painful experience in China and resulting sexual 
anxieties, but it is also a reflection on Chinese history and politics. On a metaphorical level, You's injury illustrates China's repression of sexuality. The sexual repression and political oppression of contemporary China literally and metaphorically castrated him, directly associating his traumatic experience of politicisation with sexual potency. You's sexual anxieties thus function as a trope for the extremely pervasive and diffuse nature of biopolitics in contemporary China. His sexual anxieties articulate the structure of After China, inform his binary representation of China, but also involve a critique of biopolitics and its impact on individual sensibilities and intimacies.

In a 1995 article on Brian Castro's novels, Peter Pierce remarked that Castro "is not a satirist, but one positively - if cunningly and covertly - committed to the transvaluation of what has been sacred and unquestioned in Australia for so long". ${ }^{37}$ After China does not transvalue what has been sacred and unquestioned in Australia - it challenges the stifling presence and enforcement of biopolitical logics in contemporary Chinese society, questioning issues that are forcibly left unquestioned in China.

\section{Notes}

1 Brian Castro is a contemporary Australian writer who has published nine novels. Born in 1950 in Hong Kong in a family of mixed English, Chinese and Portuguese descent, he immigrated to Australia at the age of eleven.

2 Such emphasis on the central role of China is absent from the French translation of After China, which is entitled L'Architecte chinois ("The Chinese Architect"). Such change encourages readers to focus on the significance of You's profession rather than on the centrality of China, and therefore guides French readers to a sensibly different understanding of the novel. Brian Castro, L'Architecte chinois, trans. of After China by Isabelle Lee, La Tour d'Aigues, Éditions de l'Aube, 2003.

3 Brian Castro, After China, Second Edition, Adelaide, Lythrum Press, 1992, 2003, p.37. Subsequent page references to After China are mentioned in brackets in the body of the text.

4 For a discussion of the writer's illness as cancer, see Michael Deves, "Apart from the Expected': The Novels of Brian Castro", Unpublished PhD Thesis, The Flinders University of South Australia, 1999, p.207, pp.214-215.

5 "Ancient China" should here be understood to refer in very general terms to ancient and imperial China. The narratives take place before the sixteenth century, with stories occurring before Christ (Laozi, Zhuangzi), and in the seventh, ninth, fourteenth and sixteenth century.

6 Katharine England, "Introduction" in After China, by Brian Castro, Second Edition, Adelaide, Lythrum Press, 2003, p.vi.

7 Katharine England, "Introduction" in After China, by Brian Castro, Second Edition, Adelaide, Lythrum Press, 2003, p.vi.

8 Katharine England, "Introduction" in After China, by Brian Castro, Second Edition, Adelaide, Lythrum Press, 2003, p.vii.

9 David Brooks, "The Scheherezade Motif in Recent Australian Fiction Set in China and Southeast Asia" in Interactions: Essays on the Literature and Culture of the Asia-Pacific Region, Dennis Haskell and Ron Shapiro (Eds.), Nedlands, WA, University of Western Australia Press and University of Western Australia, Centre for Studies in Australian Literature, 2000, p.82.

10 Laozi is transcribed "Lao-tzu" in the novel. Although the spelling of Chinese names does not follow the pinyin system in After China, in this article Chinese names are transcribed in pinyin whenever possible to avoid confusions.

Recent scholarship has stressed the fact that Laozi was actually a latecomer in the philosophy of Taoism, which can be seen to have started with Huangdi, the Yellow 
Emperor. John Blofeld, Taoism: The Road to Immortality, Boulder, Colo., Shambhala, 1978, p.19.

11 Foucault's examination of ancient cultures mostly deals with ancient Greece, ancient Rome and ancient China. Michel Foucault, The Use of Pleasure: The History of Sexuality Volume 2, trans. Robert Hurley, London, Penguin, 1984, 1992, pp.117-118, p.120.

12 Michel Foucault, The Use of Pleasure: The History of Sexuality Volume 2, trans. Robert Hurley, London, Penguin, 1984, 1992, p.118.

13 Robert Hans van Gulik, Sexual Life in Ancient China: A Preliminary Survey of Chinese Sex and Society from ca. 1500 B.C. till 1644 A.D., Leiden, Brill, 1961, p.47.

14 Robert Hans van Gulik, Sexual Life in Ancient China: A Preliminary Survey of Chinese Sex and Society from ca. 1500 B.C. till 1644 A.D., Leiden, Brill, 1961, p.46.

15 John Blofeld, Taoism: The Road to Immortality, Boulder, Colo., Shambhala, 1978, p.118.

16 The chapter's suggestion that Laozi used sexual alchemy in his pursuit of immortality and spirituality is a clear parodic twist. The Daodejing does not include a reflection on sexual alchemy, which was developed from the work.

17 Blofeld thus reminds us that a fourth-century Taoist alchemist rejected sexual yoga because it was used as pretext to lure women into sexual relations under the pretence of accomplishing a high spiritual quest. John Blofeld, Taoism: The Road to Immortality, Boulder, Colo., Shambhala, 1978, p.118.

18 The current medical assertion that numerous ejaculations lessen the risk of developing prostate cancer adds more irony to Castro's suggestion: in After China, Laozi is killed by his own philosophy.

Interestingly, the Chinese translator of After China explained that the first chapter of the novel was omitted from the Chinese translation as it was deemed too disrespectful and subversive for a Chinese audience (Liang Fen, "Castro's After China in China" in Wenche Ommundsen (Ed.), Bastard Moon: Essays on Chinese-Australian Writing, Otherland 7, 2001, p.85). Castro deplored this change (among others in the Chinese translation) in an essay whose title clearly conveys his disappointment towards such censorship: "Masked Balls: Or, All Translators are Faithless" (Brian Castro, Looking For Estrellita, Queensland, Queensland University Press, 1999, pp.125-136). Castro's anger is understandable, all the more as the first chapter of After China is essential to the rest of the novel not only because it sets the tone for the novel, but also because it introduces major characters and themes: the character of Laozi, whose presence and anxieties articulate much of After China, and anxieties over time, sex and writing.

19 Quoted in Thomas Cleary, The Essential Tao: An Initiation into the Heart of Taoism Through the Authentic Tao Te Ching and the Inner Teachings of Chuang-tzu, New York, Harper Collins, 1991, p.80.

20 Castro also parodies Taoism through fictional characters. You's stories on Doctor Lü Ta-ching offer a stinging parody that playfully explains historical catastrophes through the clumsiness of the doctor. A Taoist alchemist, Lü strives to invent an elixir of immortality, which has unfortunately so far "killed practically everyone who drank it" (p.119). Lü's other achievements include being "single-handedly credited with having caused the demise of the Yüan regime by poisoning [...] Fang Kuo-chen” by advising him to drink his elixir of immortality (p.120). Not satisfied with being responsible for the downfall of a regime, Lü goes on to accidentally discover gunpowder, use it in the presence of Europeans and hence facilitate colonial expansion. Lü invents gunpowder unintentionally, believing he had discovered a new aphrodisiac, and Europeans discovered gunpowder by witnessing "an exploding flare between [Lü's] legs" (p.124). The possibility of colonial expansion is thus presented as the result of petty Taoist experimentations with sexuality, aphrodisiacs and immortality.

21 For instance, the image of the butterfly recurs throughout the novel: while it is a sexual position for Laozi, at other points in the novel it represents a symbol of sensuality and/or transience.

22 The very last chapter of the novel indeed mentions that You is partly paralysed: "He had developed a kind of paralysis, as if one side of him had become weighty and unwieldy, as though he were overcome by immense inertia and weariness" (p.150).

23 Zhuangzi's story is also significant in the sense that it links You's stories on ancient 
China - their references to butterflies and Zhuangzi and reflections on mortality - with his own practice of architecture as explained in his story on architect Joseph Paxton and the Crystal Palace. In the narrative, You explained that Paxton managed to build the structure for the Crystal Palace thanks to his observation of Amazon water lilies, thus positioning lilies as an essential symbol of mastery, strength, but also impermanence. The importance of Paxton's story pertains to You's own architectural practice, since the principle of impermanence is at the centre of his fascination with metabolist architecture, a movement that worked to produce flexible buildings that were impermanent and constantly subject to evolution. The story of Zhuangzi thus ties the impermanence of sex and life with the impermanence of architecture. In its final triumphant catharsis, the butterfly (and therefore You) establishes "a balance between brevity and duration", an intricate encounter between sex and architecture (p.148).

24 The aunt's praise of moderation may also be seen as a critique of the lack of moderation that characterised some of the policies of the communist government not only in its discard of history but also in the magnitude of campaigns such as the Great Leap Forward and the Cultural Revolution, which are evoked in negative terms in the novel.

25 This argument is highly reminiscent of Mikhail Bakhtin's criticism of authoritarian regimes. Bakhtin argued that authoritarian states only allow a single voice, and that heteroglossia - a variety of voices - consequently represents a subversive and threatening act. Mikhail M. Bakhtin, The Dialogic Imagination: Four Essays, trans. C. Emerson and M. Holquist, Austin, University of Texas Press, 1981, 1998, p.343.

26 This nostalgia is present in most of Castro's fictional evocations of China, not least in Shanghai Dancing, where the golden age of Shanghai (pre-1937 Shanghai) is repeatedly mourned. Brian Castro, Shanghai Dancing, Artarmon, NSW, Giramondo, 2003, 2004.

27 You's description of a dark, oppressive, crowded China contrasts with a vast, bare, mundane Australia. Australian lives are "so settled, so uneventful" (p.29). Unlike China, Australia is sparsely populated and fundamentally large: the hotel restaurant is "gigantic", its steaks "huge but unappetising" (p.70). The safety and comfort of Australia is unattractive and linked to a sense of waste. Although China "is much worse than Kafka's stories" (p.5o) in the novel, its cacophony is fundamentally desired as exciting and homely.

28 The novel traces an evolution from every day terror in China to peacefulness and calm. At the end of the novel, You celebrates his liberation from fear: "There was one thing that was certain: his fear had evaporated" (p.151).

29 The Great Leap Forward (1958-1961) was a disastrous economic and social plan promoted by the Chinese government. One part of the plan involved a campaign to kill all sparrows, which were blamed for stealing seeds and ruining harvests. Sparrows primarily died of exhaustion because they were continually chased when they landed and therefore kept from resting. The extermination of sparrows caused a major imbalance in China's ecology, resulting in the multiplication of insects, which in turn ruined crops, contributing to a catastrophic three-year famine.

30 Michel Foucault, The Use of Pleasure: The History of Sexuality Volume 2, trans. Robert Hurley, London, Penguin, 1984, 1992, pp.170-171.

31 Brian Castro, Looking For Estrellita, Queensland, Queensland University Press, 1999, pp.75-96.

32 Brian Castro, Looking For Estrellita, Queensland, Queensland University Press, 1999, p.88.

33 See in particular the three volumes of Foucault's The History of Sexuality.

34 Michel Foucault, "Il faut défendre la société » : cours au Collège de France (1975-1976), Paris, Gallimard, 1997, pp.213-214. Foucault dates the emergence of biopower to the eighteenth century and the development of capitalist logics ( Il faut défendre la société » : cours au Collège de France (1975-1976), Paris, Gallimard, 1997, pp.213-214). In Homo Sacer, Giorgio Agamben argues that the development of biopolitics can be traced back to ancient Rome, thus approaching the notion as constitutive of power itself rather than as the result of capitalist modes of governing (Giorgio Agamben, Homo Sacer: Sovereign Power and Bare Life, Stanford, Stanford University Press, 1998).

35 Michel Foucault, "Il faut défendre la société » : cours au Collège de France (1975-1976), Paris, Gallimard, 1997, pp.214-217. 
36 Michel Foucault, Surveiller et punir : naissance de la prison, Paris, Gallimard, 1975, p.138.

37 Peter Pierce, “Things are Cast Adrift': Brian Castro’s Fiction”, Australian Literary Studies,17.2, October 1995, p.152.

\section{Pour citer cet article}

Référence électronique

Marilyne BRUN, « "After China, It Had Been Impossible": China, History and Sexual Anxiety in Brian Castro's After China », Transtext(e)s Transcultures 跨文本跨文化 [En ligne] , 6 | 2011 , mis en ligne le 05 avril 2011, Consulté le 26 avril 2011. URL:

http://transtexts.revues.org/index403.html

\section{Auteur}

\section{Marilyne BRUN}

Marilyne Brun completed a PhD in Australian studies at Université Toulouse-Le Mirail, France, and the University of Melbourne, Australia, in November 2010 and is currently teaching at Université Jean Moulin Lyon 3 in France. Her research interests include Australian literature, culture and history, diasporic literatures, critical race theory and hybridity. She has published articles on Brian Castro's work and hybridity theory. Marilyne Brun a obtenu un doctorat en études australiennes de l'Université de Toulouse-le Mirail et de The University of Melbourne (Australie) en novembre 2010, et est Attachée Temporaire d'Enseignement et de Recherche à l'Université Jean Moulin Lyon 3. Ses thèmes de recherche incluent la littérature, la culture et l'histoire australiennes, les littératures diasporiques, la théorie raciale et le métissage. Elle a publié des articles sur l'œuvre de Brian Castro et sur la théorie du métissage.

\section{Droits d'auteur}

() Tous droits réservés 